\title{
THE DISTRIBUTION OF THE FISHES OF THE ORDER OSTARIOPHYSI
}

\author{
BY \\ C. TATE REGAN, M.A., F.R.S. \\ Keeper of Zoology in the British Museum (Natural History)
}

The Ostariophysi are Teleostean Fishes in which the air bladder is connected with the internal ear by a chain of ossicles, the Weberian ossicles, which are modified elements of the anterior vertebrae. Although the order is a large and varied one it is undoubtedly natural, and its importance in Zoogeography arises from the fact that it is dominant in the fresh waters of all parts of the world except Madagascar and the Australian Region.

I estimate the number of known species at well over 4,000 ; of these more than 2,500 are $\mathrm{Cy}$ prinoids (Characiniformes 850, Gymnotiformes 30, and the rest Cypriniformes, with nearly 1,500 Cyprinidae) and about 1,600 are Siluroids.

In 1911 (Regan, 7) I proposed the following classification of the

Order OSTARIOPHYSI.

Sub-order 1. CYPRINOIDEA.

Division 1. Characinif ormes.

Families Characinidae, Gastropelecidae, Xiphostomatidae, Anostomidae, Hemiodontidae, Citharinidae.

Division 2. Gy mnotiformes.

Families Rhamphichthyidae, Sternarchidae, Gymnotidae, Electrophoridae.

Division. 3. Cy prin if ormes.

Families Cyprinidae, Catostomidae, Homalopteridae, Cobitidae.

Sub-order 2. Siluroidea.

Families Diplomystidae, Siluridae, Bagridae, Amiuridae, Amblycepidae, Sisoridae, Amphiliidae, Chacidae, Schilbeidae, Clariidae, Pangasiidae, Mochocidae, Malopteruridae, Doradidae, Pimelodidae, Helogenidae, Hypophthalmidae, Trichomycteridae, Bunocephalidae, Callichthyidae, Loricariidae, Ariidae, Plotosidae.

The two sub-orders are well marked, the Cyprinoidea being the more generalized; were it not for the presence of the Weberian mechanism these would be placed in the same group of Fishes as the Salmon and the Herring, the most primitive group of Fishes with a truly homocercal caudal fin (cf. Regan, 6).

All the Ostariophysi are strictly fresh-water fishes with the exception of two families of Siluroids, Ariidae and Plotosidae, mariy of which occur on coasts and in estuaries, the former in all warm countries, the latter only in the Indo-Pacific. There can be little doubt that this marine habit is secondary, and although it has an important bearing on the distribution of these two families, which are the only Ostariophysi found in the Australian Region or in Madagascar, it has none on that of the order as a 
whole, for both the Ariidae and the Plotosidae are highly specialized families and none of the other Siluroids can be regarded as derived from them.

In this connection it is interesting to note that the only fossil Siluroids known from marine or estuarine deposits can be definitely referred to the Ariidae. Arius itself dates back to the Middle and Upper Eocene of England and Belgium; two extinct genera described from the Eocene of Egypt appear to be related to Arius (STROMER, 12); finally I have examined Bucklandium, from the Lower Eocene (London Clay) which shows quite clearly the inferior process at the junction of the basioccipital with the vertebral column, which is diagnostic of the Ariidae. In the form of the skull Bucklandium comes nearer to Ancharius of Madagascar than to any other known genus.

Here seems the place to mention the extraordinary comparison of the Cretaceous teeth known as Onchosaurus with those of the living African genus Hydrocyon, on which was founded the theory that the Characinidae were marine in Cretaceous times (cf. Eastman, Bull. Amer. Mus. XXXVII, 1917, p. 757; Boulenger, C.R. Acad. Sci. Paris CLXVI, 1918, p. 197 and P.Z.S. 1918, p. 195).

When this view was put forward at a meeting of the Zoological Society in April, 1918, I pointed out that these teeth differed in shape, structure and attachment, and that the resemblance between them was of the most superficial kind, those of Onchosaurus being solid, with external ridges near the base, and with a longitudinal groove on the lower surface, whilst those of Hydrocyon are hollow, with the thin wall of enamel thrown into numerous folds towards the base for attachment to a series of radiating ridges in the socket; they are in fact rather like the teeth of Lepidosteus. I then supposed that Onchosaurus belonged to the Enchodontidae, which have solid teeth of this type, but the whole matter has been happily cleared up by STROMER (Abhandl. Bayerisch. Akad. XX́VIII (8) 1918, p. 17) who has shown that the teeth called Onchosaurus are the rostral teeth of a Saw-fish.

Leaving aside the Ariidae and Plotosidae we may consider the Ostariophysi as true fresh-water fishes; it seems probable that the Weberian mechanism was evolved as an adaptation to life in freshwater and that the dominance of the group is due to its possession, for there can be little doubt that, as was maintained by SöRENSEN, this apparatus transmits to the internal ear vibrations which the airbladder receives from outside (cf. KuIPER, Proc. Akad. Amsterdam XVIII, 1916, p. 572) and that this increased sensitiveness is especially useful in fresh-water conditions. There is every reason for believing that the evolution of the Ostariophysi has taken place in fresh-water and that their dispersal has been accomplished by hydrographical changes, such as the capture by one river of the tributaries of another, the union of rivers brought about by elevation of the land, etc. a very slow process when compared with the dispersal of terrestrial animals. From the distribution of such a group one may draw important conclusions with regard to former land connections or ancient lines of severance.

The distribution of the existing fishes of the order (excluding the Ariidae and Plotosidae) may be summarized as follows.

The Ostariophysi are found in America, Eurasia and Africa; they are absent from Madagascar and from the Australian Region (including Celebes and the islands eastwards).

The Characiniformes are African and Neotrcpical. The Characinidae, the largest and most generalized family, is the only one common to Africa and South America, and the only one of the American families that ranges north of Panama, extending to southern Mexico, and in the lowlands of the Atlantic slope even to the Rio Grande. There are about 500 species of Characinidae in S. America and 50 in Africa; there is a much greater diversity and specialization in America than in Africa. Two African genera, Hydrocyon and Ichthyoborus, are highly specialized, but most of the African species belong to Alestes and allied genera, which are closely related to the South American Brycon. The Gastropelecidae (6 spp.) Anostomidae (150 spp.) Hemiodontidae (60 spp.) and Xiphostomatidae (8 spp.) are peculiar to South America and the Citharinidae (60 spp.) to Africa.

The Gymnotiformes (30 spp.) are South American, one species ranging northwards to Guatemala; this group includes the Electric Eel; it is related to the Characiniformes, but is very aberrant.

The Cypriniformes are characterized by the toothless mouth and by the falciform lower pharyngeals, provided with teeth which bite upwards against a horny pad supported by the basioccipital; they inhabit Eurasia, Africa and North America. The Cyprinidae (nearly 1500 species) have the same range as the whole group, but the Indian Region is their headquarters. 
The Cyprinidae may be divided into three main groups, the Bariliines, the most primitive, with the cleithra pointed anteriorly, the Leuciscines, with truncated cleithra, and the Cyprinines, in which the anterior ends of the cleithra are emarginate. The Bariliines are most abundant in the Indian Regian, but there are a few Palaearctic genera; Barilius itself extends into Africa, where there are also 2 or 3 small endemic genera related to it. The Leuciscines are characteristic of and almost restricted to the Palaearctic and Nearctic regions; all the American Cyprinidae, about 200 species, belong to this group. The Cyprinines show their greatest development in the Indian Region; some Indian genera, Barbus, Labeo, etc. have numerous species in Africa: Barbus also reaches Europe. Characteristic Palaearctic genera of this group are Gobio, Saurogobio, etc. Tinca, Cyprinus and Carassius; Oreinus, Schizothorax and their allies are found in Central Asia.

The Catostomidae are a well marked family, confined to North America, except that Catostomus catostomus extends from Alaska into Siberia and that China has a peculiar genus, Myxocyprinus, related to Ictiobus. The southernmost species is an Ictiobus in Guatemala.

The Homalopteridae and Cobitidae are characteristic of hill-streams, the former in Southern Asia, the latter well represented also in the Palaearctic Region, especially in Central Asia.

The most primitive living Siluroid is Diplomystes papillosus of Chile, where it survives as a remnant of an ancient fauna, cut off from the competition of the more up-to-date forms, about 800 in number, which people the rivers of tropical America. The other South American families are the Doradidae, Pimelodidae, Helogenidae, Hypophthalmidae, Trichomycteridae, Bunocephalidae, Callichthyidae and Loricariidae. Of these the Pimelodidae may be regarded as ancestral to several of the others and they alone extend north of Panama, reaching southern Mexico.

Although Africa and India have three families of Siluroids in common, Bagridae, Schilbeidae and Clariidae, the genera are distinct, except for two genera of Clariidae, Clarias and Heterobranchus. Most, if not all, of the African and Indian families other than the Bagridae may be regarded as derived from that family, which appears to be nearly related to the South American Pimelodidae; two Indian Bagrid genera, Liocassis and Pseudobagrus, extend through China to the Amur.

The Amphiliidae, Mochocidae and Malopteruridae are peculiar to Africa, which has about 250 species of Siluroids; the Sisoridae, Amblycepidae and Siluridae are important Indian families, with a few palaearctic representatives.

The Amiuridae are scarcely distinct from the Bagridae. This family is peculiar to North America except for a species of Amiurus in China; the most southerly species inhabits the River Balsas in Mexico.

The following zoogeographical regions may be recognized.

1. Australia, with the islands east of WALLACE's Line.

No Ostariophysi except Ariidae and Plotosidae, which have a number of endemic fresh-water genera.

2. Madagascar.

No Ostariophysi except Ancharius (Ariidae).

3. Neotropical Region - South and Central America.

Characiniformes, Gymnotiformes, Siluroidea (9 endemic families).

4. Ethiopian Region - Africa.

Characiniformes. Cyprinidae (Indian genera).

Siluroidea (3 families in common with India, 3 endemic).

5. Indian Region - India and S. E. Asia.

Cyprinidae (Bariliinae and Cyprininae). Cobitidae.

Homalopteridae. Siluroids numerous.

6. Palaearctic Region - Europe; Asia to the Himalayas and the Yang-tse-kiang. Cyprinidae (mostly Leuciscines); Cobitidae; few Siluroids.

7. Nearctic Region. - N. America.

Leuciscine Cyprinidae, Catostomidae, Amiuridae.

GüNTHER (4) recognized a southern region (Patagonia, New Zealand etc.) and BERG $(1,2)$ a northern one, including all the arctic rivers of Europe and North America; but the chief character of 
each of these is a negative one, the paucity of true fresh-water fishes, whilst the only positive feature is the presence of migratory marine fishes or of fresh-water species derived from them, in the north Coregonus and Salvelinus, in the south Galaxias and Haplochiton. Berg includes China in the Indian Region, but the relationships of its Cyprinidae are so clearly with those of Europe that I cannot accept this, and I regard the Palaearctic Region as comprising 3 sub-regions (1) Europe, Western Asia and Siberia (2) Central Asia (3) Eastern Asia (Amur to Yang-tse-kiang).

Fossil Ostariophysi are known from many tertiary deposits (Woodward 13); as mentioned above the Siluroids found in marine and estuarine beds prove that the family Ariidae dates back to early Eocene times. In North America the Green River shales (Middle Eocene) of Wyoming include fragmentary remains of several species of Rhineastes, a Siluroid that has been said to show relationships with the Pimelodidae and Ariidae (COPE 3). Comparing a skeleton of Amiurus caudafasciatus with COPE's descriptions and figures I find that the basioccipital of Rhineastes calvus is almost identical with that of the modern species, having an inferior pit with shallow groove-like pits in front of it, and also showing agreement in the position and structure of the surfaces for the attachment of the lower limbs of the supra-cleithra. The somewhat later Amyzon beds include Amyzon, a Catostomid nearly related to the living Ictiobus, and another Rhineastes (R. pectinatus), which shows resemblances to Amiurus in the broad ventral union of the cleithra and hypocoracoids and in having the complex vertebra deeply grooved below. Catostomus is found in the lower Tertiary of Idaho, but Cyprinidae are not known from North America before the Miocene. No fossils of importance are known from South America or Africa, but in Europe we find that Tinca and Leuciscus date back to the Oligocene and several other modern European genera of the Cyprinidae to the Miocene.

In Asia the Lignites of Sumatra (probably Miocene) and the Pliocene deposits of the Siwalik Hills include examples of several living Indian genera of Cyprinidae and Siluroids.

The palaeontological evidence as to the past history of the Ostariophysi is very imperfect, but several important facts emerge. These are that none of the families is known to have had in former times a more extended range than at present, that some highly specialized families were in existence in the Eocene, that the characteristic Nearctic families, Catostomidae and Amiuridae, were already established in North America in Eocene times, and finally that nearly all the fossils are generically identical with living species and that the few extinct genera are not very clearly distinguished from modern ones.

It is quite clear that the Ostariophysi date back to the Cretaceous. So far as their structure is concerned there is no improbability in this, for the Characins are not very remote from the Elopidae and Ichthyodectidae, which were abundant in Cretaceous times, whilst the Leptolepidae, hardly distinct from the Elopidae, date back to the Lower Lias.

Whilst some geologists believe in the permanence of the great ocean basins and explain similarilies in the faunas of S. America and Africa as due to migration from the north, others think that in past times the distribution of land and water has been very different from what it is at present, and that a former direct connection between the two continents may account for some of the resemblances in their faunas. The evidence from the distribution of the Ostariophysi lends strong support to the latter view.

It seems reasonable to believe that in early Cretaceous times S. America and Africa formed one continent, which must have extended to India, not, however, through Madagascar, as has often been supposed. In this continent the Ostáriophysi originated and evolved, so that when it was broken up towards the end of the Cretaceous there were at least Characinidae and Pimelodidae in South America, Characinidae and Bagridae in Africa, and Cyprinidae and Bagridae in Southern Asia. The subsequent history of South America is simple; it was isolated and developed its rich and remarkable fauna of endemic families of Characins, Gymnotiformes and Siluroids; at the beginning of the Miocene it became connected with Central America, which has been colonized by immigrants from the south, but none of these has gained access to the Mexican Plateau and very few have made their way northwards into the Atlantic streams of Mexico. Scarcely any nearctic fishes have reached Central America and none South America.

The distinctness of the African and Indian Schilbeidae makes it probable that this family was 
established in both regions in prae-tertiary times. The endemic African families, Citharinidae, Amphiliidae, Mochocidae and Malopteruridae, developed in Africa, the first from the Characinidae, the others from the Bagridae. Africa was isolated during the Eocene and owes its Cyprinidae to a subsequent invasion from Asia.

India and S.E. Asia has been the centre of evolution of the Cypriniformes. In late Cretaceous times India appears to have separated from Africa and it probably became connected with Eastern Asia towards the end of the Cretaceous, allowing the Cypriniformes to spread northward, so that the ancestors of the well marked Nearctic family Catostomidae reached North America by a bridge across the Bering Straits well before the Eocene, together with the Bagrid ancestors of the Amiuridae.

The Palaearctic Ostariophysi are obviously related to and derived from those of Southern Asia; the most characteristic group, the Leuciscine Cyprinidae, is derived from the more primitive and more southern Bariliinae. It seems quite likely that the Cyprinidae did not reach Europe from Asia until the Oligocene, and that North America, isolated during the Eocene, again became connected with Asia in Oligocene times, giving an Amiurus and a Catostomid genus to Asia and receiving Leuciscines from it.

So far as Australia is concerned it seems clear that it has not been connected with S.E. Asia during the time that the latter has been inhabited by Ostariophysi. WALLACE's Line seems to mark the ancient severance between the two regions, which probably dates back to Cretaceous times. Nothing can be more striking than a comparison between Borneo, with its iich and varied fauna of fresh-water fishes, and Celebes, without a single indigenous true fresh-water fish. The evidence for the long isolation of Madagascar is also very strong.

The above suppositious history of the dispersal of the Ostariophysi is, I believe, on the whole fairly in accordance with a considerable body of geological opinion. The alternative view, that the Ostariophysi originated in the north and spread southwards, involves so many improbabilities as to be almost unbelievable. 


\section{LIST OF PAPERS}

1. BeRG, L. S. Fischfauna des Amur-Flusses, mit Bezug auf die Frage von den zoogeographischen Regionen für die Süsswasserfische. Zool. Jahrb. Abt. Syst. XXXII, 1912, p. 475.

2. - Les Poissons des eaux douces de la Russie Moscow. 1916.

3. COPE, E. D. Rep. U. S. Geol. Surv. Territ. III, 1884.

4. Günther, A. The Study of Fishes (1881).

5. REGAN, C. T. Biologia Centrali-Americana. Pisces. (1906-1908).

6. - The Caudal Fin of the Elopidae and of some other Toleostean Fishes. Ann. Mag. Nat. Hist. (8) V, 1910, p. 354.

7. - - The Classification of the Teleostean Fishes of the Order Ostariophysi. Ann. Mag. Nat. Hist. (8) VIII, 1911. Cyprinoidea p. 13; Siluroidea, p. 553.

8. - Wallace's Line. Rep. Brit. Ass. 1911, p. 433.

9. -- "Fishes". British Antarctic (Terra Nova) Expedition Zoology I p. 1. [Faunal relationship between S. America and Australia].

10. - - "Reptilia, Batrachia and Pisces" [Origin and dispersal of Nearctic and Neotropical groups]. Biologia CentraliAmericana. Introductory Volume, p. 105 (1915).

11. - - Freshwater Fishes from Madagascar. Ann. Mag. Nat. Hist. (9) V, 1920, p. 419.

12. STROMER, E. Nematognathi aus dem Fajum und dem Nationthale in Aegypten. Neues Jahrb. f. Mineralogie, 1904, I, p. 1.

13. Woodward, A. S. Catalogue of Fossil Fishes. IV, (1901). 